\title{
Nocardia farcinica as a cause of chronic meningitis - case report
}

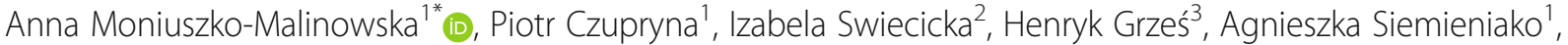 \\ Sambor Grygorczuk', Eugeniusz Tarasów ${ }^{4}$ and Sławomir Pancewicz ${ }^{1}$
}

\begin{abstract}
Background: Nocardiosis is an uncommon disease caused by aerobic gram-positive bacteria Nocardia spp. Although it is usually an opportunistic infection affecting immunocompromised patients, even one third of cases occur in immunocompetent persons. The aim of the study was to describe the course of chronic meningitis due to Nocardia infection.

Case presentation: A 52-year-old patient, chalk miner, suffered from a chronic meningitis caused by an extremely rare pathogen. The patient's history was complicated and diagnostic process covered multiple examinations and consultations. Initially Kocuria rosea was cultured, yet after molecular examination the result was verified to Nocardia farcinica. Targeted antibiotic treatment was implemented, which resulted in gradual improvement of patients condition. A full recovery was achieved after one year antibiotic therapy.

Conclusions:

1. Nocardia farcinica is an uncommon but possible cause of chronic meningitis.

2. In the case of a chronic meningitis of unknown origin multiple cerebrospinal fluid cultures should be performed as the identification of pathogen may be crucial for patient's recovery.

3. In case of unusual culture, such as Kocuria spp. PCR should be performed.
\end{abstract}

Keywords: Nocardia farcinica, Meningitis

\section{Background}

Nocardiosis is an uncommon disease caused by aerobic gram-positive bacteria Nocardia spp. [1]. It is an opportunistic infection, which usually affects immunocompromised patients, however one third of patients with nocardiosis may be immunocompetent. Nocardiosis may present as a single organ or multifocal disease. The single organ infection most commonly manifests as a lung disease (39\% of hospitalized patients) or CNS disease ( $9 \%$ of patients). The aim of the study was to describe the course of chronic Nocardia meningitis.

* Correspondence: annamoniuszko@op.pl

${ }^{1}$ Department of Infectious Diseases and Neuroinfections, Medical University

of Białystok, Zurawia 14; 15-540, Bialystok, Poland

Full list of author information is available at the end of the article

\section{Case report}

A 52-year-old patient, chalk miner, was admitted to the regional hospital for investigation of sa 2-week history of severe headache and fever. Physical examination revealed fever, pain on palpation in cervical and lumbosacral region, and meningeal signs. Features suggestive of bacterial meningitis were detected in the cerebrospinal fluid. The empirical antibiotic therapy with ceftriaxone and vancomycin was implemented. Subsequently vancomycin was replaced with ampicillin. CSF and blood cultures were negative (Table 1).

Because of persisting headache in spite of the treatment, MRI of the brain was performed (Table 2; Figs. 1, 2, 3 and 4).

Patient was consulted by a dentist - decayed teeth and maxillary cysts were observed. The cyst was surgically removed and sanitation of oral cavity was performed. Enterobacter cloacae was cultured from the cyst,

C) The Author(s). 2020 Open Access This article is distributed under the terms of the Creative Commons Attribution 4.0 International License (http://creativecommons.org/licenses/by/4.0/), which permits unrestricted use, distribution, and reproduction in any medium, provided you give appropriate credit to the original author(s) and the source, provide a link to the Creative Commons license, and indicate if changes were made. The Creative Commons Public Domain Dedication waiver (http://creativecommons.org/publicdomain/zero/1.0/) applies to the data made available in this article, unless otherwise stated. 
Table 1 Results of CSF examinations

\begin{tabular}{|c|c|c|c|c|c|c|c|}
\hline Data & 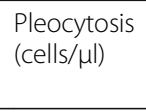 & $\begin{array}{l}\text { Lymphocytes } \\
\text { (\%) }\end{array}$ & $\begin{array}{l}\text { Granulocytes } \\
\text { (\%) }\end{array}$ & $\begin{array}{l}\text { Monocytes } \\
(\%)\end{array}$ & $\begin{array}{l}\text { Protein } \\
\text { concentration } \\
\text { (mg/dL) }\end{array}$ & $\begin{array}{l}\text { Glucose } \\
\text { concentration } \\
\text { (mg/dL) }\end{array}$ & CSF culture \\
\hline 02.02.2015 & 2240 & - & - & - & 1609 & 13 & No growth \\
\hline 09.02 .2015 & 246 & 53 & 43 & 4 & 125.7 & 26 & No growth \\
\hline 20.02.2015 & 135 & 90 & 3 & 7 & 83.4 & 39 & No growth \\
\hline 03.03.2015 & 2770 & 9 & 88 & 3 & 159 & 24 & Growth of Kocuria spp., \\
\hline 16.03.2015 & 1463 & 20 & 80 & - & 146.1 & 34 & Growth of Kocuria spp., \\
\hline 27.03. 2015 & 1731 & 10 & 85 & 5 & 169.9 & 16 & $\begin{array}{l}\text { Growth of Kocuria spp., finally diagnosed } \\
\text { as Nocardia farcinica with PCR }\end{array}$ \\
\hline 07.04 .2015 & 1438 & 16 & 84 & - & 159.6 & 26 & No growth \\
\hline 20.04 .2015 & 460 & 10 & 90 & - & 194.6 & 21 & No growth \\
\hline 20.06.2015 & 350 & - & - & - & 166.4 & - & No growth \\
\hline 18.08.2015 & 191 & 22 & 73 & 5 & 131.9 & 31 & No growth \\
\hline 07.10 .2015 & 15 & - & - & - & 46.6 & 53 & No growth \\
\hline 05.01 .2016 & 12 & 58 & 42 & - & 32.7 & 53 & No growth \\
\hline
\end{tabular}

followed with meropenem and amikacin treatment according to the antibiogram. Because of the persisting symptoms the patient was transferred to the Department of Infectious Diseases and Neuroinfections, Medical University of Bialystok, Poland.

Antibiotic therapy was continued. Patient received meropenem, aminoglycosides, ciprofloxacin, which resulted with remission of fever and headache, as well as meningeal signs and pain on palpation in cervical and lumbosacral region. However, with the antibiotic withdrawal the symptoms reappeared. Additionally, cerebellar symptoms and sensory disturbances appeared.

Multidirectional diagnostic protocol was implemented: latex test of CSF (Neisseria meningitidis B, E.coli K1 (-); Haemophilus influenzae $\mathrm{b}(-)$; Streptococcus pneumoniae (-); Streptococcus B (-); Neisseria meningitidis A (-); Neisseria meningitidis C (-); Neisseria meningitidis Y/W 135 (-) Pastorex Meningitis; BIORAD), syphilis tests, bacterial and fungi cultures, DNA hybridization test and culture for Mycobacterium tuberculosis, multiplex-PCR CSF for

Table 2 Results of imaging tests

\begin{tabular}{|c|c|}
\hline Data & Brain MRI results \\
\hline 30.12 .2014 & $\begin{array}{l}\text { - Widening of the posterior anchor of the left lateral } \\
\text { - Ventriculitis } \\
\text { - Widened Robin-Virchoff Virchow-Robin area on the left side }\end{array}$ \\
\hline 13.03.2015 & $\begin{array}{l}\text { - Inflammatory enhancement of meninges } \\
\text { - Inflamatory lesions in the anterior part of cereberral tent } \\
\text { - Asymmetry of occipital horns } \\
\text { (Figs. 1, 2,3 and 4) }\end{array}$ \\
\hline 06.10 .2015 & $\begin{array}{l}\text { - Regression of lesions } \\
\text { - Lesions in occipital horns similar to the previous } \\
\text { examination }\end{array}$ \\
\hline 16.03 .2016 & $\begin{array}{l}\text { - Further regression of lesions } \\
\text { - Post inflammatory changes }\end{array}$ \\
\hline
\end{tabular}

viruses (HSV-1, HSV-2, VZV, EBV, CMV, HHV-6), CSF cytology. All results were negative. The patient was consulted by otolaryngologist, ophthalmologist, neurosurgeon, dentist, and psychiatrist. Numerous neuroimaging examinations (US, X-ray, CT, MRI) were performed (Table 2).

Subsequent CSF cultures were negative (Table 1). Finally in the 4th, 5th and 6th CSF culture, Gram-positive cocci were cultured. Whitish, small, round, raised, convex colonies of $2-3 \mathrm{~mm}$ size on initial isolation and nondiffusible yellowish pigmentation after prolonged incubation were observed. Initially with the use of GP identification cards and automatic systems VITEK 2 (bioMerieux) the bacteria were identified as Kocuria spp.

In the molecular examination, genomic DNA of the bacteria was extracted from an overnight culture in a brain-heart infusion (BHI) broth using the DNeasy Blood \& Tissue Kit (Qiagen GmbH, Hilden, Germany) with the protocol for Gram-positive bacteria. The DNA concentration and its purity were assessed in the NanoDrop 2000 spectrometer (Thermo Fisher Scientific Com., Waltham, USA). Then, a pair of primers 27F $5^{\prime}$ AGAGTTTGATCMTGGCTCAG-3' and 1525R 5'AAGGAGGTGWTCCRCC-3' [2] were used to amplified the $16 \mathrm{~S}$ rRNA gene of the isolate in PCR performed in the Veriti 96 Well thermal cycler (Applied Biosystems, Foster City, USA) at the following conditions:: $94{ }^{\circ} \mathrm{C}$ for 3 min, 30 cycles $94{ }^{\circ} \mathrm{C}$ for $30 \mathrm{~s}, 56^{\circ} \mathrm{C}$ for $45 \mathrm{~s}$, and $72{ }^{\circ} \mathrm{C}$ for $90 \mathrm{~s}$, and the final elongation for $7 \mathrm{~min}$ at $72^{\circ} \mathrm{C}$. The PCR product was analyzed in a gel electrophoresis and purified with the QiaAmp PCR purification kit (Qiagen). The sequencing reaction was performed using the Big Dye Terminator cycle sequencing kit (Applied Biosystems); the product was purified using the ExTerminator Kit (A\&A Biotechnology) and sequenced with the 


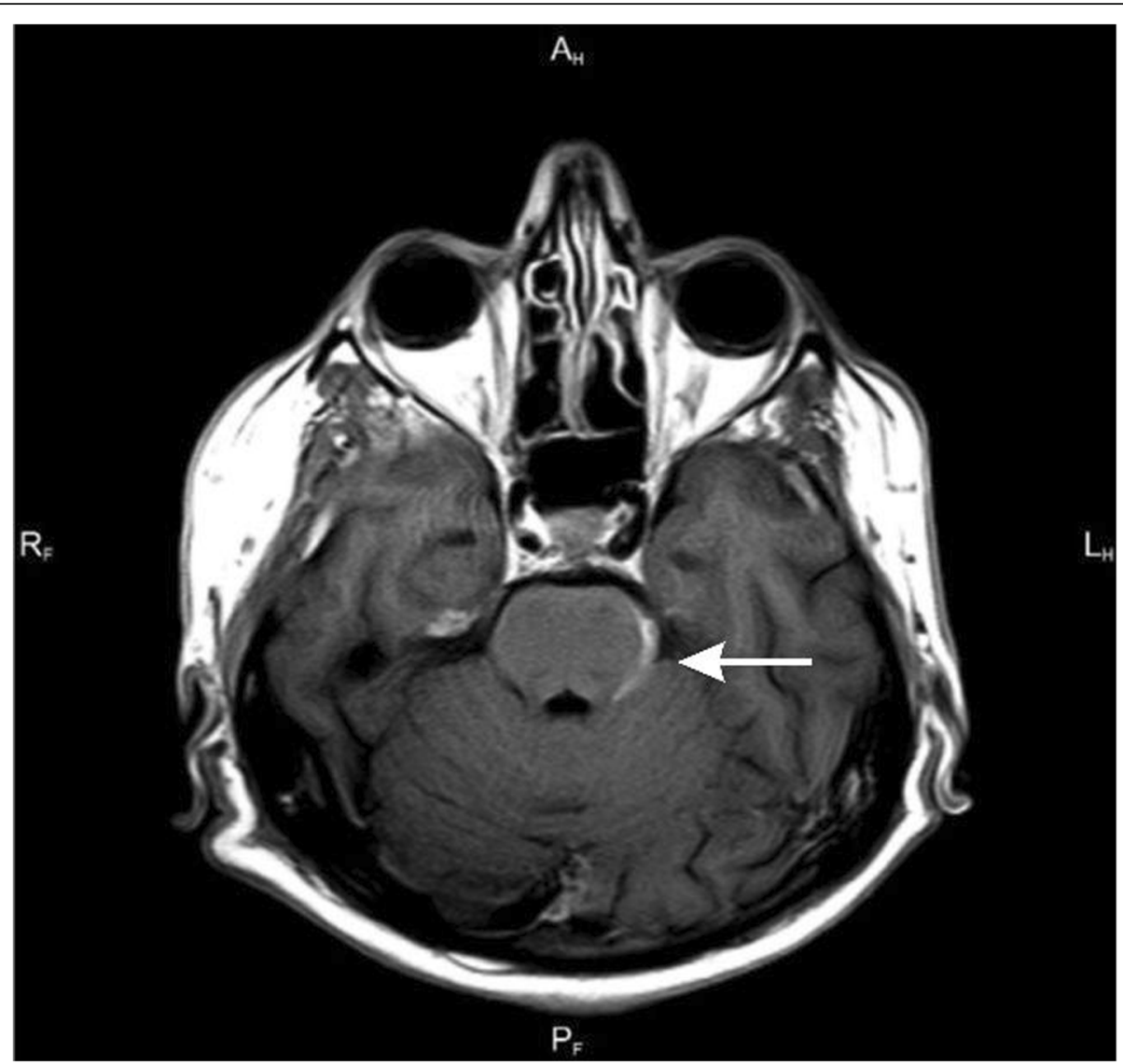

Fig. 1 Axial T1-weighted scan after contrast enhancement - contrast enhancement of the left lateral surface of the pons

ABI3500 automated sequencer (Applied Biosystems). The sequences were assembled with the BioEdit Sequence Alignment Editor version 7.0.1. For the comparative analyses of nucleotide and amino acid sequences, database searches were performed using the BLAST programs at the NCBI website (http://www.ncbi. nlm.nih.gov). This study allowed verification of the initial identification to Nocardia farcinica.

Treatment with trimethoprim / sulfamethoxazole was initiated, resulting in slow improvement of patient's condition, regression of cerebellar symptoms and sensory disturbances, and decrease in the inflammatory parameters of the CSF. The total duration of treatment was 1 year and resulted in complete recovery.

\section{Discussion and conclusions}

Nocardia spp. is present in soil and may be transmitted through direct inhalation of contaminated particles. In case of our patient, working in a chalk mine might therefore be considered a risk factor of Nocardia spp. infection.

Nocardiosis usually presents as a self-limiting respiratory tract infection. However, in some patients Nocardia spreads from lungs to other organs with a particular affinity for the brain. The most common neurological symptoms in the course of nocardiosis are: focal neurologic abnormalities, altered mental status, seizures, visual changes, ataxia. Nocardial meningitis is an infrequent manifestation of CNS nocardiosis and can occur with or without an associated brain abscess [3]. In our patient the disease presented initially only with fever and headache, with cerebellar syndrome and sensory disturbances appearing later in the course of the infection.

As Nocardia spp. are relatively slow-growing bacteria that can be challenging to recover, multiple CSF specimens should be cultured to increase the yield, although it is not uncommon for the bacteria to be recovered only when direct pus is cultured [4]. In routine aerobic cultures, Nocardia spp. have variable colonial morphology, from chalky white to pigment-producing orange, yellow, or brown colonies [5]. The preferred methods for speciation of Nocardia are 16S rRNA gene analysis and other molecular techniques, such as restriction fragment length polymorphisms and multilocus sequence analysis.

In our case the 4th culture was at first mistaken for Kocuria rosea, which morphologically resembles Nocardia. Only the following molecular diagnosis allowed us to 

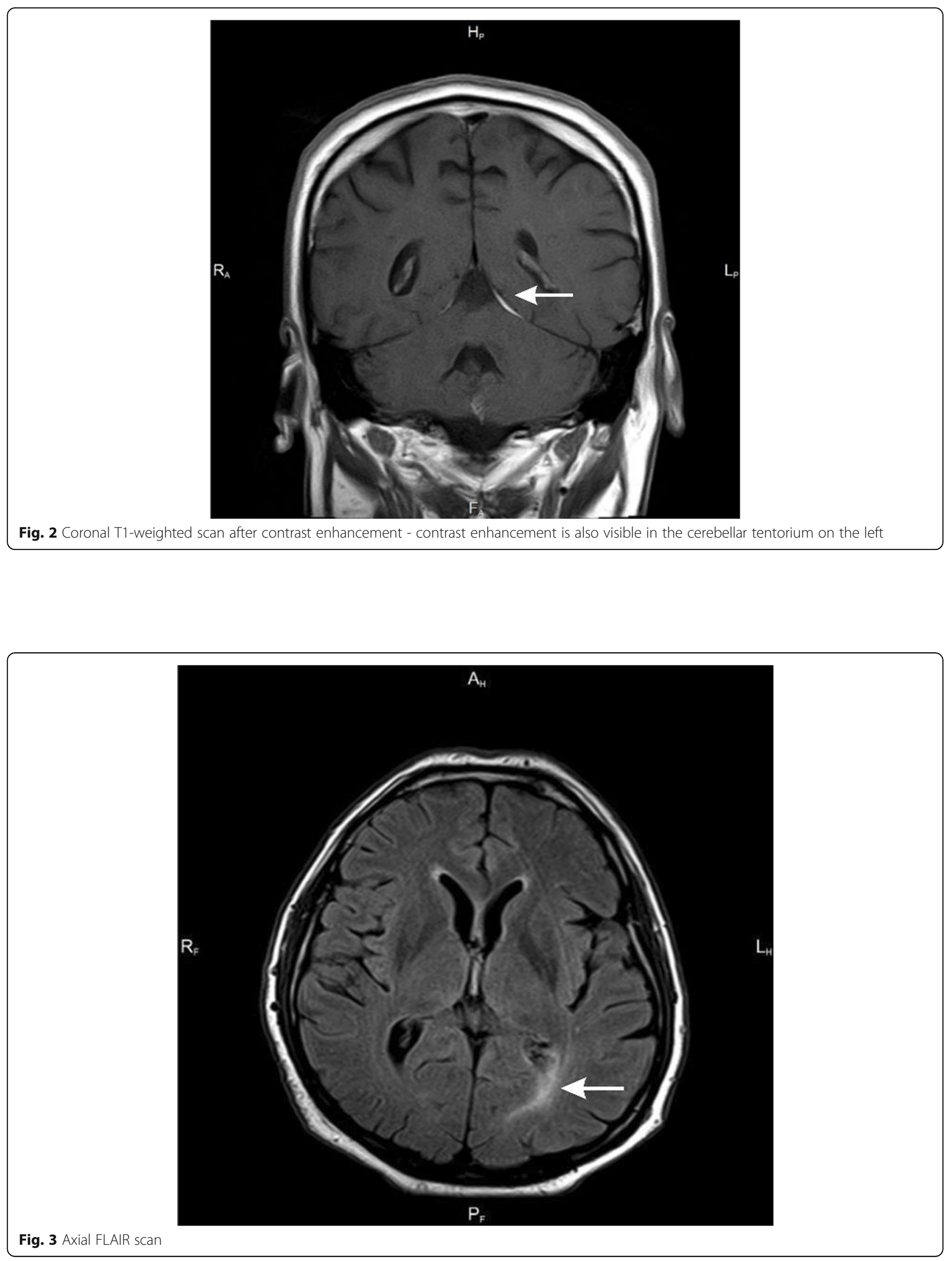


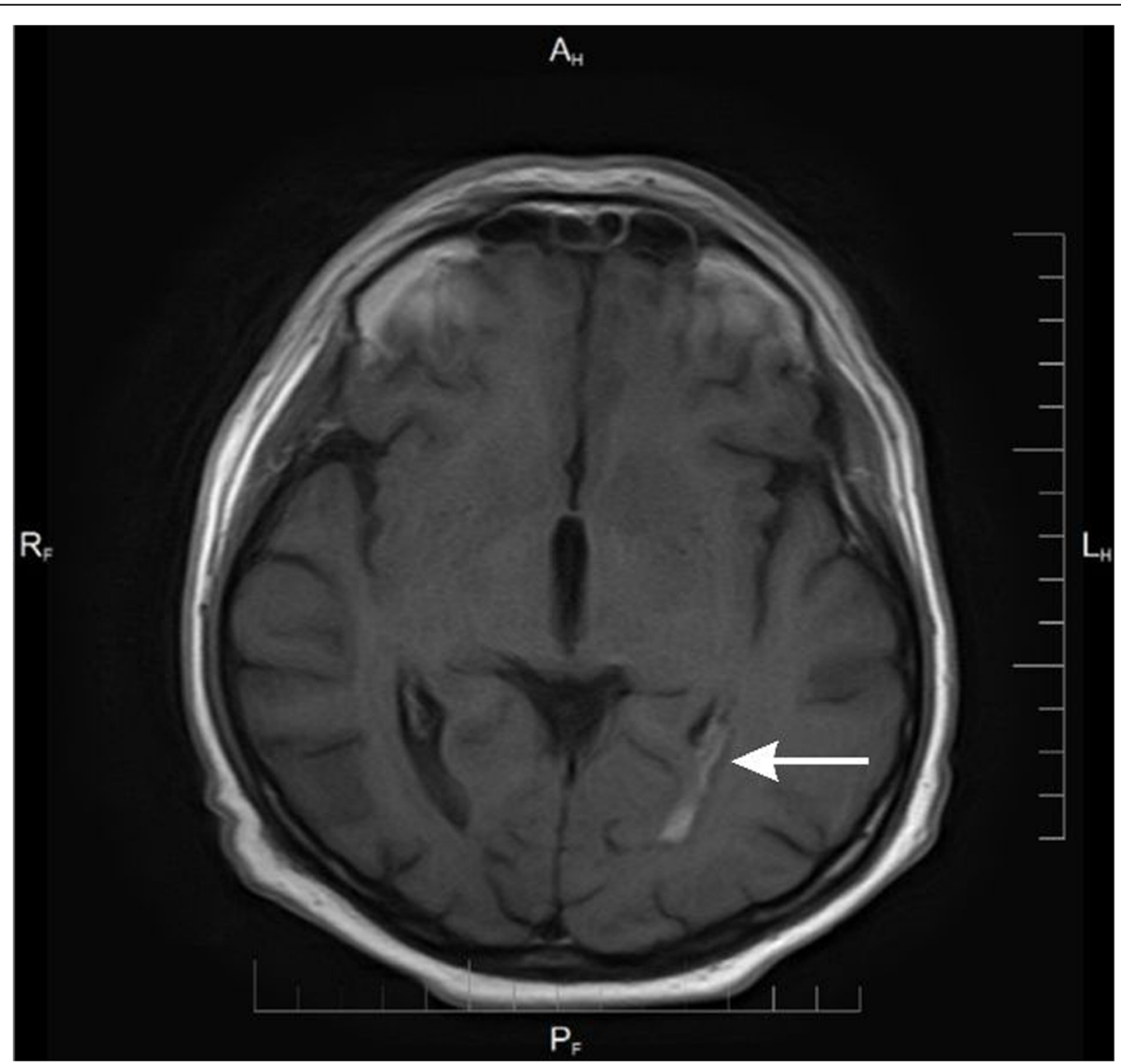

Fig. 4 Axial T1-weighted scan after contrast enhancement - Enhancing lesion in choroid plexus of the left occipital temporal horn of the lateral ventricle with surrounding edema visible in FLAIR scan

properly identify the pathogen and adjust the treatment. Only molecular diagnosis differentiated Nocardia farcininca from Kocuria rosea.

Most authorities recommend trimethoprimsulfamethoxazole (TMP-SMX) as part of first-line therapy for nocardiosis [6]. In case of our patient treatment with TMP-SMX resulted with a complete recovery.

Based on our experience we concluded, that:

1. Nocardia farcinica is an uncommon but possible cause of chronic meningitis.

2. In the case of chronic meningitis of unknown origin multiple cerebrospinal fluid cultures should be encouraged as the identification of pathogen may be crucial for patient's recovery.

3. In case of unusual culture, such as Kocuria spp. PCR should be performed.

\section{Abbreviations}

CMV: Cytomegalovirus; CSF: Cerebrospinal fluid; CSN: Central nervous system; $\mathrm{CT}$ : Computer tomography; EBV: Epstein barr virus; HHV-6: Human herpes virus - 6; HSV-1, HSV-2: Herpes simples virus - 1; 2; MRI: Magnetic resonance; TMP-SMX: Trimethoprim-sulfamethoxazole; US: Ultrasonography;

VZV: Varicella zoster virus

\section{Acknowledgements}

Not applicable.

\section{Availability of data and material}

The raw data can be requested from Corresponding Author: annamoniuszko@op.p

\section{Authors' contributions}

All authors read and approved the final version of the manuscript and ensure this is the case: AMM, PCZ, SP - analyzed and prepared the data, wrote the manuscript; IS, HG - performed analyses, AS, SG - were the leading doctors, ET - performed imaging studies with its critical analysis.

Our manuscript reporting adheres to CARE guidelines.

\section{Funding}

No funding.

Ethics approval and consent to participate Not applicable.

\section{Consent for publication}

Written informed consent for the publication of identifying images or other personal or clinical details of participant that compromise anonymity was obtained.

\section{Consent for publication}

Is available for the Editor.

Competing interests

All Authors declare no conflict of interests. 


\section{Author details}

'Department of Infectious Diseases and Neuroinfections, Medical University of Białystok, Zurawia 14; 15-540, Bialystok, Poland. ${ }^{2}$ Department of Microbiology, University of Bialystok, Ciołkowskiego 1J, 15-245, Bialystok, Poland. ${ }^{3}$ Microbiology Laboratory, University Hospital in Białystok, Zurawia 14; 15-540, Bialystok, Poland. ${ }^{4}$ Department of Radiology, Medical University of Białystok, Białystok, Poland.

Received: 17 May 2019 Accepted: 3 January 2020

Published online: 17 January 2020

\section{References}

1. Davis J, Kreppel AJ, Brady RC, Jones B, Stevenson CB, Fouladi M, Hummel TR. Nocardia farcinica meningitis masquerading as central nervous system metastasis in child with cerebellar pilocytic astrocytoma. J Pediatr Hematol Oncol. 2015;37(6):482-5.

2. Kuzu SB, Güvenmez HK, Denizci AA. Production of a Thermostable and Alkaline Chitinase by Bacillus thuringiensis subsp. kurstaki Strain HBK-51. Biotechnol Res Int. 2012;2012:135498.

3. Anagnostou T, Arvanitis M, Kourkoumpetis TK, Desalermos A, Carneiro HA, Mylonakis E. Nocardiosis of the central nervous system: experience from a general hospital and review of 84 cases from the literature. Medicine (Baltimore). 2014;93(1):19-32.

4. Chow FC, Marson A, Liu C. Successful medical management of a Nocardia farcinica multiloculated pontine abscess. BMJ Case Rep.2013; 2013: bcr2013201308.

5. Corti ME, Villafañe-Fioti MF. Nocardiosis: a review. Int J Infect Dis. 2003;7(4): 243-50.

6. Budzik JM, Hosseini M, MackinnonAC TJB. Disseminated Nocardia farcinica: literature review and fatal outcome in an Immunocompetent patient. Surg Infect. 2012;13(3):163-70,

\section{Publisher's Note}

Springer Nature remains neutral with regard to jurisdictional claims in published maps and institutional affiliations.

- fast, convenient online submission

- thorough peer review by experienced researchers in your field

- rapid publication on acceptance

- support for research data, including large and complex data types

- gold Open Access which fosters wider collaboration and increased citations

- maximum visibility for your research: over $100 \mathrm{M}$ website views per year

At BMC, research is always in progress.

Learn more biomedcentral.com/submissions 